\title{
Assessing the impact of support structures and initiatives to youth entrepreneurship development in a selected Township in the Western Cape Province of South Africa
}

\author{
Saphetha Appie Gwija \\ Department of Entrepreneurship and Business Management, Faculty of Business, Cape Peninsula \\ University of Technology, South Africa. Email: sgwija@gmail.com \\ Chuks Eresia-Eke \\ Department of Business Management, University of Pretoria, South Africa \\ Email: chuks.eresia-eke@up.ac.za \\ Chux Gervase Iwu \\ Department of Entrepreneurship and Business Management, Faculty of Business, \\ Cape Peninsula University of Technology, South Africa.Email: iwuc@cput.ac.za
}

\section{Doi:10.5901/mjss.2014.v5n1p61}

\section{Abstract:}

This study sought to determine the role of government support structures and initiatives in the development of youth entrepreneurship in Khayelitsha, in the Western Cape Province of South Africa. The data was collected by way of questionnaires, whereby 132 participants were randomly drawn from the population of 200 youth entrepreneurs who were registered on the database of a local organisation for youth entrepreneurs in Khayelitsha. According the findings, there was no evidence to show that government support structures/initiatives were contributing in the development of youth entrepreneurship in this township. Recommendations to improve the current standard of youth entrepreneurship in the research setting were made. This paper provides an insight into the role of youth entrepreneurship support structures and initiatives in Khayelitsha, particularly to stakeholders such as government structures, which seek to advance youth entrepreneurship in Khayelitsha and others townships, in Western Cape.

Keywords: Youth entrepreneurship, Support structures and initiatives, Youth Development, Khayelitsha, Western Cape, South Africa

\section{Introduction}

A host of challenges is facing today's youth around the world, particularly the less-developed countries, such as South Africa. These include challenges of employment and employability; poverty alleviation; crime and violence including gangs at schools and in the; drug and alcohol abuse; exposure to HIV and Aids pandemic; and the spread of the internet, which appears to be wrongly utilised by some of young people. For young people, as leaders of tomorrow, the establishment of significant strategies tailored to nourish and develop their well-being should be the governments' priority. According to the World Bank report, by 2015 young people the age of 25 will approximately total 25 billion in the globe (Youth Business International, 2009). Despite the affirmative predictions that this generation will be the most educated ever, the International Labour Organisation's (ILO's) statistics envisage a decline in job creation opportunities. Dreadfully, ILO's statistics further reveal that $40 \%$ of the youth are unemployed and have little chances of finding jobs when they are adults (Youth Business International, 2009). As a strategic approach to enhance young people's position towards self-employment, academics, practitioners and policy makers in the globe have heightened their commitment towards fostering entrepreneurial mindset in societies (European Commission, 2003). The emergence of entrepreneurship plays a fundamental role in economic growth, economic competitiveness, job creation, as well as improvement of social welfare in the country (Dempsey, 2009).

Interestingly, after the fall of the apartheid era in South Africa, government introduced policies (see National Youth Policy, 2009) and development initiatives, which include the National Small Business Act of 1996, with the aim to provide an enabling business environment, in particular for women, Black people, rural areas, and youth among others (Nieman 
and Nieuwenhuizen, 2009). In spite of having received intensive consideration since the establishment of Umsobomvu Youth Fund (UYF) in 2001 (Nieman and Nieuwenhuizen, 2009), youth entrepreneurship development in South Africa remains unsatisfactory. Mostly, this appears to be the case in rural areas and other Township communities in the country, where thousands and thousands of young people from the countryside have migrated to with the hope of finding greener-pastures. Von Broembsen et al. (2005) in Fatoki and Chindoga (2011) argue that South Africa's youth lag behind in the setting up of business ventures of their own, compared to their counterparts from other countries. Clearly this does not augur positively for youth economic participation, particularly in a current job-hostile environment in South Africa, where the unemployment rate among youth was recently estimated at 70\% (Fatoki and Chindoga, 2011). Herrington et al. (2009) assert that the weakness of youth to engage in entrepreneurship, encumbers on the state's limited budget, as it (the State) mostly invests its resources on young people through education, health and social grants (Mkoka, 2012).

Research reveals that in South Africa, there is a host of challenges that entrepreneurs encounter. These challenges include start-up and expansion capital, regulatory red-tape, lack of interest to engage in entrepreneurship, lack of awareness about entrepreneurial support structures, inadequate skills, lack of access to markets, and so on (Atieno, 2009; Herrington, 2010; Nieman and Nieuwenhuizen, 2009; Pretorius and Shaw, 2004; Succeed, 2006; Van Dijk, 2008; Western Cape Youth Report, 2008). On the basis of impressive strategic plans and objectives of government-pioneered support structures and initiatives aimed to improve entrepreneurship development (Chabane, 2011; South Africa. DTI, 2009), and other private institutions in the country (see literature relevant to study section), the state of youth entrepreneurship should not be as scary it was reported (Von Broembsen et al., 2005 in Fatoki and Chindoga (2011). Hence, this paper seeks to find out the exact role that government support structures and initiatives are currently playing in developing youth entrepreneurship in Khayelitsha, a township in the Western Cape Province of South Africa. Khayelitsha is a less advantaged community, which is dominated by Black South Africans who speak IsiXhosa.

Specifically, this study poses following question:

* What is the role of government support structures and initiatives in the development of youth entrepreneurship in Khayelitsha, Western Cape?

The objective below will help to answer the above mentioned research question.

* To find out the role of government support structures and initiatives in the development of youth entrepreneurship in Khayelitsha, Western Cape.

The relevance of this study is aligned to its capacity to provide insight into youth entrepreneurship development and youth support structures and initiatives in the selected township, which is quite uncertain, as a result of insufficient research in the field of entrepreneurship. Furthermore, findings and recommendations in this study will bring to light the current position of youth entrepreneurship, to stakeholders, particularly government structures, which are tailored to advance youth entrepreneurship in Khayelitsha, and other townships in the Western Cape Province.

\section{Literature review}

It is a well-established fact that youth group differ across regions and from one country to another (see UNOWA, 2005; African Union, 2006; International Labour Office, 2006). In South Africa the youth includes young people who are within the ages 14-35 years (National Youth Policy, 2009). Owing to the current and historical imbalances, which have not yet been fully dealt with, in South Africa, the upper age limit of the youth remains 35 years (National youth Policy, 2009). Nonetheless, in the context of this paper, youth are defined as those individuals who are between the ages of 16 and 35 .

Within the field of entrepreneurship, writers have and are still struggling to produce a single and commonly acceptable definition of entrepreneurship (Kobia and Sikalieh, 2010; Davey, Plewa and Struwig, 2011). Kobia and Sikalieh (2010) argue that the reason for this is because entrepreneurship has been studied in a variety of disciplines, and this has augmented diverse views around its meaning. Nonetheless, within the context of this paper, entrepreneurship is defined as a process to create or use opportunities, with the help of acquired resources to start, acquire or grow an existing business with the primary intention of making a profit. Owing to their creativity and innovation, entrepreneurs create new technologies, products and services that add value and solve society problems (Nicolaides (2011). The emergence of youth entrepreneurship aids economic independence, minimizes reliance of youth 
on grants from government, boosts their self-esteem, and improves their standards of living, and may also results in political stability and national security of a country (Fatoki and Chindoga, 2010).

As indicated earlier in the introduction of the study, in South Africa, an extensive focus on youth entrepreneurship was made after the establishment of Umsobomvu Youth Fund (UYF) in 2001. The latter aimed to foster entrepreneurial attitudes among youth, through paving a way to finance and market access, among other things (Nieman and Nieuwenhuizen, 2009). After seven years of its existence, the UYF merged with the National Youth Commission (NYC) to form the National Youth Development Agency (NYDA). This amalgamation was set out to address hindrances against the well-being of the country's youth, which included lack of economic participation, as well as engagement in entrepreneurial activities, drug and alcohol abuse and HIV and Aids (DYDA Annual Report, 2010). To this end, it is arguable that this government intervention has not yet achieved its key objectives. The fact that youth unemployment, which was recently estimated at $70 \%$, is probably at its highest magnitude ever in South Africa (Mkoka, 2012) bears ample testimony to that. Youth unemployment could result in drug and alcohol abuse which may lead to the youth participating in criminal activities. The NYDA has also established Integrated Youth Development Strategy (IYDS) and Plan for South Africa, which aims to improve youth development in the country. These initiatives are yet to manifest in any meaningful development.

South Africa's Department of Trade and Industry (DTI), with the intention of boosting economic growth and broader participation in it, has amongst others established an institutional framework to support SMMEs (Nieman and Nieuwenhuizen, 2009). The framework is known as the National Youth Economic Empowerment Strategy and Implementation Framework (NYEESIF) for 2009-2019 (DTI, 2009). The aim of the framework is to improve the quantity and quality of youth entrepreneurship and technical knowledge, minimizing poverty and unemployment among the county's youth (DTI, 2009).

There are also private institutions that are enthusiastic about improving the level of youth entrepreneurship in the country, through pioneered initiatives to youth. These include South African Breweries (SAB), which runs the Kick-start Programme to start-up and grow entrepreneurial venture amongst youth, since May 1995 (Swanepoel, Streydom and Nienwenhuizen, 2010); the Junior Achievement South Africa (JASA), a ${ }^{1}$ section 21 company with the reputation of offering business and entrepreneurial programmes to learners in and out of school, across the country over the past 30 years (JASA, 2009); the South African Youth Chamber of Commerce (SAYCC), the voice of youth entrepreneurs in South Africa, which pays more attention to youth entrepreneurship development (YED), youth leadership development (YLD), business education, skills transfer and economic advocacy programmes (SAYCC, 2010); and the Branson school of entrepreneurship (Virgin Unite, 2011).

The existence of these government support structures and private institutions' initiatives attest to the fact that fostering a mindset of entrepreneurship among youth somehow catches the interests of certain stakeholders. Nevertheless, it would auger well for youth entrepreneurship development, particularly in the Western Cape, if it turns out to be the case in the Khayelitsha Township as well, where this study is based.

\section{Research methodology}

A descriptive research design was utilised. The current study was conducted with the help of self-administered questionnaires, which were distributed to a total of 132 subjects that were randomly drawn from the population of 200 youth entrepreneurs. During the course of the investigation, all the subjects were registered on the database of a local organisation, which fosters and develops entrepreneurship among youth in Khayelitsha, in the Western Cape Province of South Africa. Survivalist youth entrepreneurs were excluded in this research, as they normally do not register with the local organisation, as they also usually operate informal businesses. The population for the current study was selected with the belief that it would supply worthwhile information, which would be relevant in the study, for the following reasons. The subjects of the study were from various sections that make up Khayelitsha.

3.1 Research instrument: The research questionnaires were personally administered by one of the researchers to the participants at a local training centre, where they held their weekly meetings. The participants were allowed the space to fill out the questionnaires (to avoid influence/interference) and were even asked not to disclose their identities. These attempts were aimed to reduce the likelihood of obtaining false information. This study made use of a

${ }^{1} A$ section 21 company is a special kind of company that is not for profit making, which may, under the Act, only be incorporated as a company limited by guarantee (Colliers, Benade, Henning, Du Plessis, Delport, De Koker \& Pretorius, 2000:35). 
standardised and identical questionnaire for every respondent. Closed and open-ended questions, dichotomous (yes/no), filter; follow-up and 5-Point Likert Scale questions were posed. This instrument was chosen because of its ability to gather objective and unbiased information (Cupido, 2003). Out of a total of 132 questionnaires distributed among the participants, 77 of the returned questionnaires were usable for statistical analysis. Therefore, this represented a response rate of $58.3 \%$ for the study.

3.2 Reliability and validity of research instrument: Bless et al. (2006) argue that in the field of social science, there is no measurement technique that is perfect. They suggest that researchers should often assess the instrument, which they wish to use in the process of data collection, for validity and reliability purposes. A test re-test reliability evaluation was conducted on the data collection instrument of the study. A set of questionnaires was initially administered to a total of ten subjects of the current study. Another set of questions, which were identical to the previous ones, were administered to the same subjects, a couple of weeks later, and the responses that were obtained on those two occasions were assessed for consistency, and seven of them were correlated. Slight adjustments on the research instrument were made, to increase chances of reliability and validity.

\section{Presentation of the findings}

This section presents the findings of the study. Table, bars and pie chart are used to display the findings of the study while relevant discussion followed each of these.
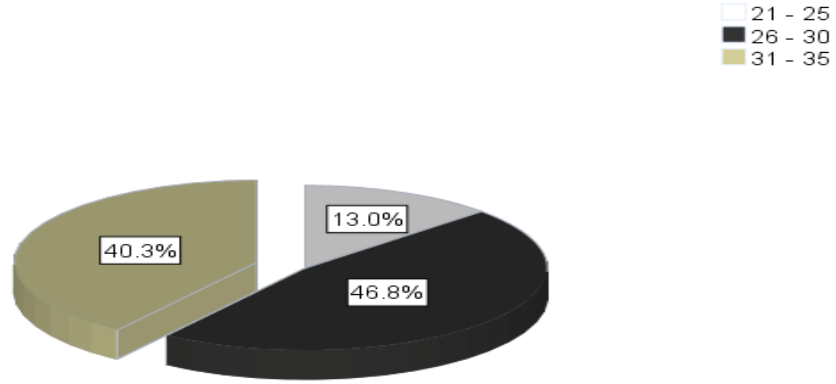

\section{Figure 4.1: Age group of youth entrepreneurs}

The figure above indicates that a majority of the participants (46.8\%) comprised those who were between the ages 26-30 years, followed by $40.3 \%$ who were between the ages of 31 and 35 . Only $13 \%$ of the participants were between the ages of 21 and 25 years. Despite the fact that in the context of this study the targeted age groups began at the ages 1620 , according to the findings this age group was not represented. A young age should not be seen as an obstacle on its own, to start business. This is because renown entrepreneurs such as Bill gates of Microsoft (Investors, 2013), Richard Branson of the Virgin Group (Branson, 2006), and others started their entrepreneurial ventures very early.

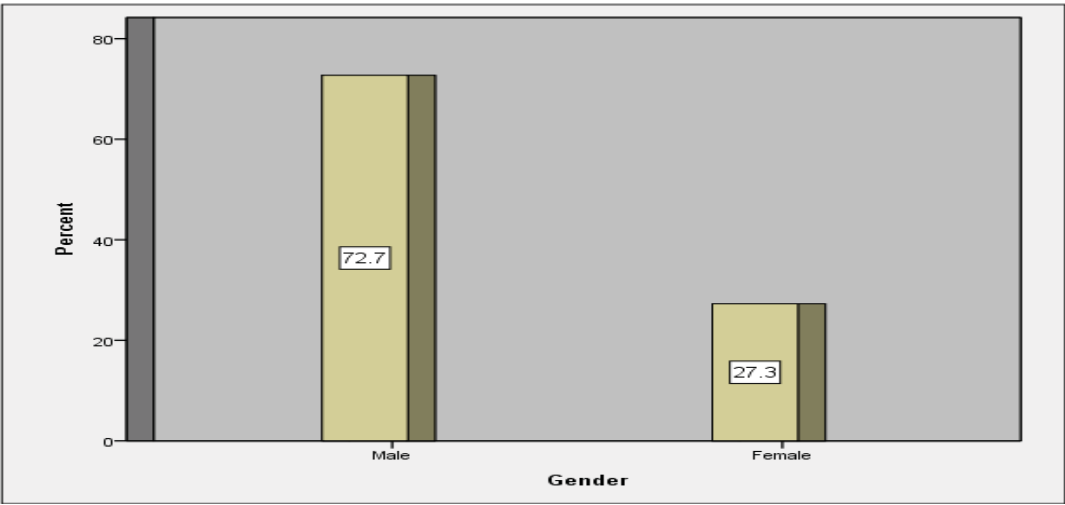

Figure 4.2: Gender of youth entrepreneurs 
Figure 4.2, above indicates that a large percentage (72.7) of the respondents were males while $22.7 \%$ were females. These findings could be associated with Fatoki and Chinga's (2011) belief that social-cultural constraints may negatively impact the engagement of young women in entrepreneurship. According to Nieman and Niewenhuizen (2009), these include personal difficulties, gender discrimination and bias, negative socio-cultural attitudes, and balancing business and family responsibilities. In South Africa, particularly in such an impoverished community as Khayelitsha, young women tend to give birth early in their lives, some even before completing high school. This may limit their chances of engaging in entrepreneurial activities and their worldview may negatively be influenced, as their priorities may begin to change.

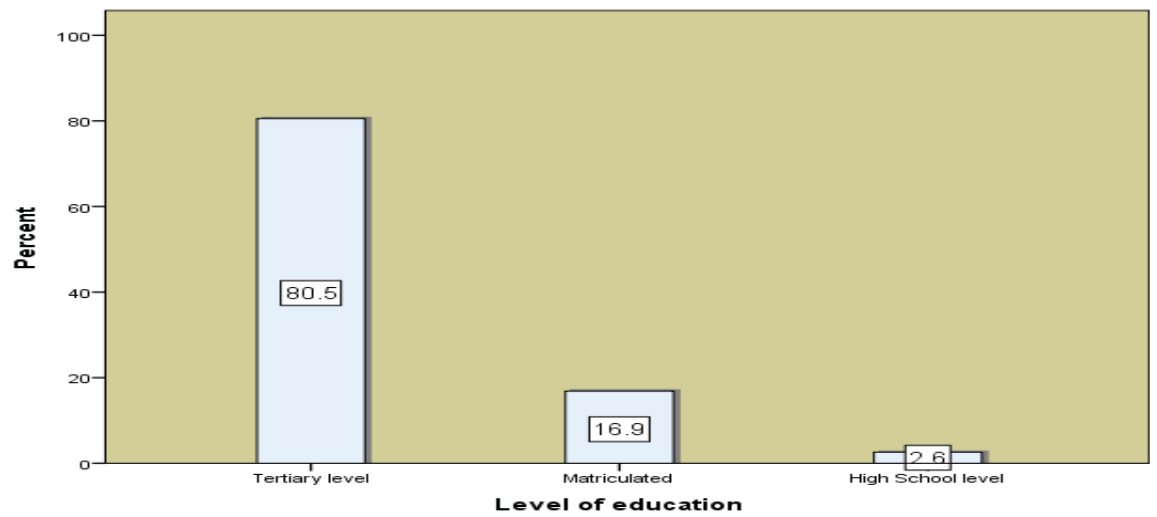

\section{Figure 4.3: Level of education of youth entrepreneurs}

The findings on the highest level of education for the participants indicate that a large portion (80.5\%) of them achieved tertiary qualifications, followed by $16.9 \%$ who completed high school. A small percentage (2.6\%) of the participants had only managed to study up to high school level. Indicatively, in spite of the fact that a majority of the participants in the study achieved tertiary education, some of them had no entrepreneurial or business related education and training. Perhaps this highlights the need for entrepreneurial and managerial skills exposure among these youth entrepreneurs, so as to be on the safe side. See figure 4.3 above.

Table 4.1: Condensed descriptive statistics of participant's responses

\begin{tabular}{|c|c|c|c|}
\hline Item & Response categories & Frequency & Valid Percentage \\
\hline \multirow{2}{*}{$\begin{array}{l}\text { Awareness about existing support structures for } \\
\text { youth entrepreneurs }\end{array}$} & Disagree & 62 & 80.5 \\
\hline & Strongly disagree & 15 & 19.5 \\
\hline \multirow{2}{*}{$\begin{array}{l}\text { Easy access to business funding for youth } \\
\text { entrepreneurs }\end{array}$} & Disagree & 55 & 71.4 \\
\hline & Strongly disagree & 22 & 28.6 \\
\hline \multirow{2}{*}{$\begin{array}{l}\text { Positive role of support structures (such as NYDA } \\
\text { and DTI) to youth entrepreneurship development }\end{array}$} & Disagree & 30 & 39.0 \\
\hline & Strongly disagree & 47 & 61.0 \\
\hline
\end{tabular}

Table 4.1 shows that all the participants indicated that they were unaware of the existing support structures for youth entrepreneurs beside the local organisation previously mentioned in this paper. Therefore, better methods to communicate across their presence, as well as for the services that they offer should be established. Alternatively, if this factor is owed to the absence of youth entrepreneurship support structures, then measures to ensure the existence of such support structures in this township should be addressed.

The findings of this study also reveal that a majority (71.4\%) of the participants disagreed that it was easy for them to obtain funding from financial institutions that support youth entrepreneurship, while $28.6 \%$ strongly disagreed. 
These findings align with a previous study (Gwija, Eresia-Eke and Iwu, 2013), which indicated that most participants started their businesses with the help of their own savings. Aspects such as lack of savings and collateral, lack of business information, and lack of access to business mentorships to assist in constructing impressive business plans, were identified as common hindrances that limited their chances of obtaining business funding, when they apply. Conversely, Pretorius and Shaw (2004), Atieno (2009), Herrington et al. (2009) and Young Upstarts (2011) also argue that access to business funding is a major stumbling block, particularly when starting a new business venture.

A majority (61\%) of participants strongly disagreed that support structures for youth entrepreneurs, such as the NYDA and DTI play a significant role in developing youth entrepreneurship in Khayelitsha, while the rest (39\%) disagreed with this position. This is particularly disappointing, since the NYDA, has a responsibility to facilitate youth entrepreneurship in the country (Chabane, 2011). It appears that in the Khayelitsha area this responsibility is not being discharged. The unavailability of NYDA's Youth Advisory Centre/s in this township bears ample testimony to this claim. Therefore, it is safe to say that the lack knowledge about youth entrepreneurship support structures is owed to nonavailability of these structures in Khayelitsha.

\section{Conclusion and recommendations}

Against the unsatisfactory business atmosphere, which Khayelitsha youth entrepreneurs may currently be experiencing, this study seeks to determine the role of government support structures and initiatives in developing youth entrepreneurship in Khayelitsha, in the Western Cape Province of South Africa. The evidence can also be traced to a previous study (Gwija, Eresia-Eke and Iwu, 2013) where most of the participants indicated that they started their venture with their own savings. Young Upstarts (2011) see business funding as a responsibility of the state. Perhaps this is owed to the fact that the government stands to benefit more in terms of taxes, economic growth, job creation opportunities, and so on, when new ventures are created and have sustenance in growth (Nieman and Nieuwenhuizen, 2009). Therefore, South African government should invest in youth entrepreneurship development initiatives in Khayelitsha.

A starting point in working towards achieving this goal would be to establish youth entrepreneurship support structures, which will offer not only business funding, but also non-financial services tailored towards the setting up of a new business venture and its growth and development in Khayelitsha. This is particularly imperative since findings in this study indicate that a large number of participants have totally disapproved that there were support structures for youth entrepreneurship available in Khayelitsha. Furthermore, after the establishment of such support structures, better marketing strategies to create awareness of their presence, as well as the services that they offer to young people should be among their primary concerns. This could also aid access to business information, which appears to be lacking in Khayelitsha.

South Africa's NYDA Annual Report (2010) argues that youth development in the country is everyone's responsibility, including government, private sector, civil society, and youth themselves. This calls for an extensive collaboration of sorts to engender entrepreneurship development. This could also help to identify the important and urgent business support services that are needed the most, and consequently provide for them. Private donors will also be able to know exactly where to locate their contribution.

In summary, the inability to access youth business support services, which include finance and non-financial products, particularly from government institutions brings about an unsatisfactory business environment. Consequently, the well-being of youth entrepreneurs in Khayelitsha, particularly those that are passionate about business may be jeopardised. Therefore, it is safe to say that government support structures in the country do not significantly discharge their responsibility toward youth entrepreneurship development in Khayelitsha. This is again disappointing, particularly hence, South Africa's NYDA Annual Report' (2011) fully acknowledges that entrepreneurial initiatives are the key drivers for youth participation in the economy. The continuity of this situation will have a negative impact on job creation opportunities, in spite the fact that entrepreneurship is acknowledged as better a solution to shrink youth unemployment (Musengi-Ajulu, 2010; Nafuka and Muyia, 2010). High unemployment leads to poverty and poor standards of living. Moreover, reliance of youth on grants from government, youth self-esteem and standards of living, and economic growth among others, may negatively be affected (see European Commission, 2003; Herrington, Kew and Kew, 2009; Dempsey, 2009; Ndedi, 2009; Nafukho and Muyia, 2009; Nieman and Nieuwenhuizen, 2009; Fatoki and Chindoga, 2011). This highlights the need for South African government to pay more attention in establishing support structures and initiatives in this township. Also, after their establishment, such support structures should interact with other 
stakeholders, such as local youth entrepreneurial organisation, schools, and so on, so as to easily identify and provide possible assistance to youth entrepreneurs who need business assistance the most.

\section{Limitations of the study}

This paper was limited to youth entrepreneurs that were registered on the database of a local organisation, which fosters and develops entrepreneurship in the Western Cape Province of South Africa. Therefore, it might not be not be worth making generalisations of its findings to other geographical areas of South Africa or elsewhere in the world, as a result of a variety of backgrounds, which may vary from one place to another. Additionally, this study concentrated on profitmaking youth entrepreneurial ventures that deal with products and services. Nonetheless, youth entrepreneurs such as corporate, social and adventure entrepreneurs are acknowledged by this study, for significant role, which they play in their respective communities and in the country's economy. A future direction of this study would be to examine the impact of youth entrepreneurship in job creation opportunities in Khayelitsha.

\section{References}

African Union. (2006). The African Youth Charter. Addis Ababa: African Union.

Atieno, R. 2009. Linkages, Access to Finance and the Performance of Small-Scale Enterprises in Kenya [online]. Available at: http://www.wider.unu.edu/publications/working-papers/research-papers/2009/en_GB/rp2009-06/. [Accessed April 2012].

Bless, C., Higson-Smith, C. and Kagee, A. (2006). Fundamentals of Social Research Methods. An African Perspective, Cape Town, Juta.

Branson, R. (2006). Screw it, let's do it. London, Virgin Books.

Chabane, C. (2011). Statement by minister in the Presidency, 2011 programme launch [online]. Available at: http://www.info.gov.za Ispeech/DynamicAction?pageid=461\&sid=18693\&tid=34032. [Accessed 28 March 2012].

Cupido, C. (2003). Barriers to entrepreneurship in the Western Cape. Unpublished MTech thesis. Cape Town, Cape Technikon.

Davey. T. Plewa, C. \& Strung, M. (2011). Entrepreneurship perceptions and career intentions of international students. Education + Training, Vol. 53 No. 5, pp.335-352

Dempsey, I. (2009). The Entrepreneurial Dialogues. State of Entrepreneurship in South Africa [online]. Available at: http://www.gibs.co.za/SiteResources/documents/The\%20Entrepreneurial\%20Dialogues\%20-\%20State\%20of\%20Entrepreneur ship\%20in\%20South\%20Africa.pdf. [Accessed 10 October 2010].

Department of Trade and Industry. (2009). The National Youth Economic Empowerment Strategy and Implementation Framework 20092019 (First Draft) [online]. South Africa. Available at: http://www.nwpyc.org.za/index2.php?option=com_docman \&task=doc_view\&gid=29\&ltemid=2. [Accessed 11 April 2012].

European Commission. (2003). The Commission's Green Paper: Entrepreneurship in Europe. London, Stationery Office Limited.

Fatoki, O. and Chindoga, L. (2011). An Investigation into the Obstacles to Youth Entrepreneurship in South Africa. International Business Research, Vol. 4 No.2, 161-169

Global Entrepreneurship Monitor. (2011). The UCT Centre for Innovation and Entrepreneurship [online]. Available at: http://www.gemconsortium.org/docs/download/2313 [Accessed 05 April 2013].

Gwija, S. A., Eresia-Eke, C. and Iwu, C. G. (2013). Challenges and prospects of youth entrepreneurship in Khayelitsha, Western Cape. Unpublished MTech Entrepreneurship Thesis. Cape Peninsula University of Technology

Herrington, M., Kew, J.and Kew, P. (2010). Global Entrepreneurship Monitor [online]. Available at: http://www.gsb.uct.ac.za/files IGEM2010Report.pdf. [Accessed 28 March 2012].

Herrington, M., Kew, J. and Kew, P. (2009). Tracking Entrepreneurship in South Africa: A GEM Perspective [online]. Available at: http://www.gsb.uct.ac.za/files/Gembook2009.pdf. [Accessed 10 June 2011].

International Labour Office (2006). Global Employment Trends for youth. Geneva, ILO Publications.

Inventors. (2013). Bill Gates - Biography and History [online]. Available at: http://inventors.about.com/od/gstartinventors la/Bill_Gates.htm. [Accessed 16 May 2013].

Junior Achievement South Africa. (2009). Enterprise Education [online]. Available at: http://www.jasa.org.za/site/index.php?option $=$ com_remository\&ltemid $=21 \&$ func=startdown\&id $=60$. [Accessed 7 July 2011].

Kobia, M. and Sikalieh, D. (2010). Towards a research for the meaning of entrepreneurship. Journal of European Industrial training, Vol. 34 No.2, 110-127

Mkoka, S. (2012). Towards integrated youth development. My Youth My Future Journal, Vol. 1 No1, 2-103

Musengi-Ajulu, S. (2010). What do we know about the entrepreneurial intentions of the youth in South Africa? Preliminary results of a pilot study [online]. Available at: http://www.uj.ac.za/EN/Faculties/management/departments/CSBD/Documents MusengiAjulu.pdf. [Accessed 07 December 2011].

Nafukho, F. M. and Muyia, M. A. H. (2010). Entrepreneurship \& Socioeconomic development in Africa: A reality or myth? Journal of European Industrial Training, Vol. 34 No.2, 96-109 
National Treasury. (2011). Confronting youth unemployment: policy options for South Africa. Discussion Paper for Public Comment [online]. South Africa. Available at: http://www.treasury.gov.za/documents/national\%20youth\%20unemployment\%20\%20Policy\%20options.pdf. [Accessed 28 March 2012].

National Youth Development Agency Report. (2010). National Youth Development Agency, Annual Report 20092010 [online]. South Africa. Available at: http://www.nyda.gov.za/index.php?option=com_:national-youth-development-agency-annual-report-0910. [Accessed 7 July 2011].

National Youth Development Agency Report. (2010). National Youth Development Agency, Annual Report 2010/2011 [online]. South Africa. Available at: http://www.nyda.gov.za/aboutus/NYDA\%20Strategy/Annual\%20Reports/Pages/default.aspx. [Accessed 20 July 2012.]

Ndedi, A. A. (2009) Entrepreneurship Training and Job creation in South Africa: Are Tertiary Institutions Filling the Gap? Journal of Contemporary Management, Vol. 6, 463-470

Nicolaides, A. (2011). Entrepreneurship - the role of Higher Education in South Africa. Educational Researc, Vol. 2 No.4, 1043-1050

Nieman, G. and Nieuwenheuizen, C. (2009). Entrepreneurship. A South African Perspective. Cape Town, Interpak Books.

Ohlhoff, S. (2008). The relationship between employees-of-choice status and employer branding. Journal of business and management dynamics. No.2, 28-35

Pretorius, R. and Shaw, G. (2004). Business plan in bank-decision making when financing new ventures in South Africa, Vol. 7 No.2, $221-241$

Succeed. (2006). Stop making your boss rich. City of Ekurhuleni, Succeed SA Magazine.

South African Youth Chamber of Commerce. (2010). Schweitzer Reinecke [online]. Available at: http:www.entrepreneurship.co.za Isouth_african_youth_chamber_of_commerce_saycc. [Accessed 07 April 2011].

Swanepoel, E., Streydom, J.W and Nienwenhuizen, C. (2010). An empirical analysis of private company's corporate social investment in SMME development in South Africa. South African Business Review, Vol. 14 No.1, 58-78

UNOWA. (2005). Youth Unemployment and regional insecurity in West Africa. West Africa, United Nations.

Van Dijk, H.G. (2008). The talent management approach to human resource management: attracting and retaining the right people. Journal of Public Administration, Vol. 43 No3.1, 385-395.

Virgin Unite. Branson School of Entrepreneurship. (2009) [online]. Available at: http://www.virgin.com/people-and- planet/blog/bransonschool-of-entrepreneurship. [Accessed 09 November 2011].

Von Broembsen, M., Wood, E., Herrington, M., Shay, D. and Sheppers, R. (2005). Global entrepreneurship monitor, South African Report. Cape Town, UCT.

Western Cape Youth Report. (2008). Western Cape Status Report of the Youth Report [online]. Available at: http://www.gsb.uct.ac.za/files/2008WesternCapeStatusoftheYouthReport.pdf. [Accessed 27August 2011].

Young Upstarts Report. (2011). Instant Grass for Virgin Unite [online]. Available at: http://www.instantgrass.com/wpcontent/uploads/2011/06/YUR.pdf. [Accessed 07 April 2011].

Youth Business International. (2009). Youth entrepreneurship. Recommendations for action [online]. Available at: http://www.pdp.com.sv/main/archivos/publicaciones/RecommendationsforAction.pdf.[Accessed 02 December 2011]. 